\title{
SUSTAINABILITY THROUGH CREATIVITY TO INCREASE REPETITIVE BUYING FOR BAKERY INDUSTRY IN INDONESIA
}

\author{
Amelia $^{1}$, Ronald $^{2}$ \\ Universitas Pelita Harapan, Surabaya Campus \\ 1amelia.fe@uph.edu \\ ${ }^{2}$ ronald.suryaputra@uph.edu
}

\begin{abstract}
One of the products in the food industry is bread, because it is one of the staple foods. Holland bakery is a company engaged in the food industry, which is an original Indonesian product that emphasizes quality and a premium impression. In this study, the author wants to examine how the influence of Display on Holland bakery, Holland bakery brand trust, Holland bakery brand familiarity, and the price that Holland bakery sells can affect purchase intensity in Holland bakery. The sample used in this study was 200 respondents of Holland bakery customer in Surabaya. The result of this research finds that from four hypotheses, all hypotheses are accepted. It is found that display, brand trust, brand familiarity, and price influence significantly to repetitive buying.
\end{abstract}

Keyword: : display, brand trust, brand familiarity, price, repetitive buying

\section{INTRODUCTION}

The existence of imported food in Indonesia has started a lot. It is proven that many products from Malaysia and Singapore are widely circulating in Indonesia. This creates competition between local products and imported products. But the Indonesian people are believed to prefer domestic products. One of the products in the food industry is bread. Bread is one of the staple foods. The entry of the bread industry in Indonesia is due to the fact that the market in Indonesia has its own uniqueness. The uniqueness of the bakery market in Indonesia is due to the large number of MSME entrepreneurs engaged in the bakery industry. Meanwhile, retailers in Indonesia sell bread but come from their own production.

Holland bakery is a company engaged in the food industry, which is an original Indonesian product that emphasizes quality and a premium impression. Currently, Holland bakery has more than 200 outlets throughout Indonesia. Holland bakery was first established as a modern bakery in 1978 in Jakarta and continues to grow until it has won various awards such as the Top Brand Award and The Most Favorite and Popular Bakery. Holland bakery offers a wide variety of products, from classic breads, sandwiches, pastries, snacks, traditional and modern cakes and offers various models of birthday and wedding cakes. Therefore Holland bakery is also known as a one stop shopping bakery because almost all types of bread can be found in Holland bakeries. 
Holand bakery is also known for its premium quality because all products are made with high quality ingredients, processed and baked under strict quality control using modern and sophisticated machines and equipment. Holland Bakery's motto is "Focus on Quality". In this study, the author wants to examine how the influence of Display on Holland bakery, Holland bakery brand trust, Holland bakery brand familiarity, and the price that Holland bakery sells can affect purchase intensity in Holland bakery.

According to Aaker and Lasser (in Delgado-Ballester et al., 2013) said that brand trust is a sense of security in the consumer's possession of a brand based on interactions with the brand, which is based on that consumers believe the brand can be trusted and are responsible for their interests and consumer welfare Holland bakery is a trusted bakery, with delicious taste, made from high quality ingredients, and always fresh every day to make consumers that Holland bakery is a product that can be trusted.

Brand Familiarity means a measure of consumer closeness to a brand where a well-known brand will get a positive response compared to a new brand. (Campbell and Wright (2008). Holland bakery is a bakery outlet that is quite well known in the community. The distinctive arrangement of outlets makes people familiar with Holland bakery. Holland bakery has also proven to be accepted in the community with the continued development of Holland bakery outlets. In determining the price, Holland bakery considers the influencing factors. Both costs in manufacturing, operational costs, competitors, and environmental factors. So that the price offered by Holland bakery can compete with similar companies.

Repetitive buying is basically an action taken by a customer where the customer responds positively to the quality of a company's goods or services and intends to repurchase or re-consume the company's products (Cronin \& Taylor, 1992). By responding well to Holland bakery, these consumers are satisfied. Repurchasing products from Holland bakery are carried out by consumers who are satisfied with the waiters and products offered by Holland bakery so they will make repeat purchases at Holland bakery.

\section{LITERATURE REVIEW}

\subsection{DISPLAY}

The stimulation of non-personal requests from a product, service to the buyer's point of view, so that buyers are directly interested in buying, is the meaning of display according to Alma (2009). According to Sopiah and Syihabuddin (2008) Display is an effort made by companies by arranging goods to direct buyers to be interested in seeing and buying them. The display displayed by Holland bakery is good by arranging the products that Holland bakery has on the shelves that support it and a comfortable shopping atmosphere. This will give a positive value compared to other bakeries. With a good arrangement, people will be interested in finding out what products are being sold. And it will make people buy back at a later date. This is supported by the theory put forward by Foster (2008) that display means attracting consumer attention and interest in a good or service and encouraging the desire to buy through direct visual appeal. Based on the theory that has been described, the following hypothesis can be formulated

H1: Display has a significant effect on Repetitive Buying 


\subsection{BRAND TRUST}

According to Ballestar (2001), Brand Trust is a feeling of security felt by consumers with a brand based on the perception that the brand can be trusted and fulfills consumer desires. Trust is the consumer's perception of reliability which is based on the experience or transaction / interaction felt by the consumer from the expectation of the satisfaction of a performance.

Research from Chaudhuri and Holbrook (2001) also shows that brands that are trusted will be purchased by consumers more often. Brands that consumers already trust are usually those brands that consumers will often buy. So as to gain trust in a brand from consumers, the greater the influence on repeat purchases, because consumers who believe are the result of previous positive interactions with a brand. Based on the theory that has been described, the following hypothesis can be formulated.

$\mathrm{H} 2$ : There is a significant effect of Brand Trust on Repetitive Buying

\subsection{BRAND FAMILIARITY}

Brand familiarity with a product or service is obtained from how often consumers are related to the experiences that have been obtained from a product or service (Alba and Hutchinson, 1987). Based on research conducted by Khasawneh (2010) consumers value products that are already known. Consumers believe that a familiar product is believed to be better than a new product. And also products that are better known (familiarity) are more preferred by buyers than new products or products that are not known. The introduction of a product (brand familiarity) will have an effect on repurchasing at a later time. Based on the theory that has been described, the following hypothesis can be formulated

H3: There is a significant effect of Brand Familiarity on Repetitive Buying

\subsection{PRICE}

According to Henry Simamora Price is an amount of money issued or charged for a product or service. Gitosudarmo (2008) argues that price is the amount of money needed to obtain certain goods and services or a combination of both. Research from Raharso, Sri (2005) proves that the price perceived by consumers has an effect to generate buying interest which then affects satisfaction so as to create loyalty. Based on the theory that has been described, the following hypothesis can be formulated

H4: There is a significant effect of Price on Repetitive Buying

\subsection{REPETITIVE BUYING}

Repetitive buying is something that describes consumers who have the possibility, make plans or are willing to buy a product or service in the future. This increase in purchase intention means an increase in the likelihood of purchase (Dodds et al, 1991; Schiffman and Kanuk, 2007). Researchers can also use purchase intention as an important indicator for predicting consumer behavior. When 
consumers have the intention to buy this positive form of commitment to a brand, that the brand is positive and good.

\subsection{THEORITICAL FRAMEWORK}

Theoritical framework in this research is as follow:

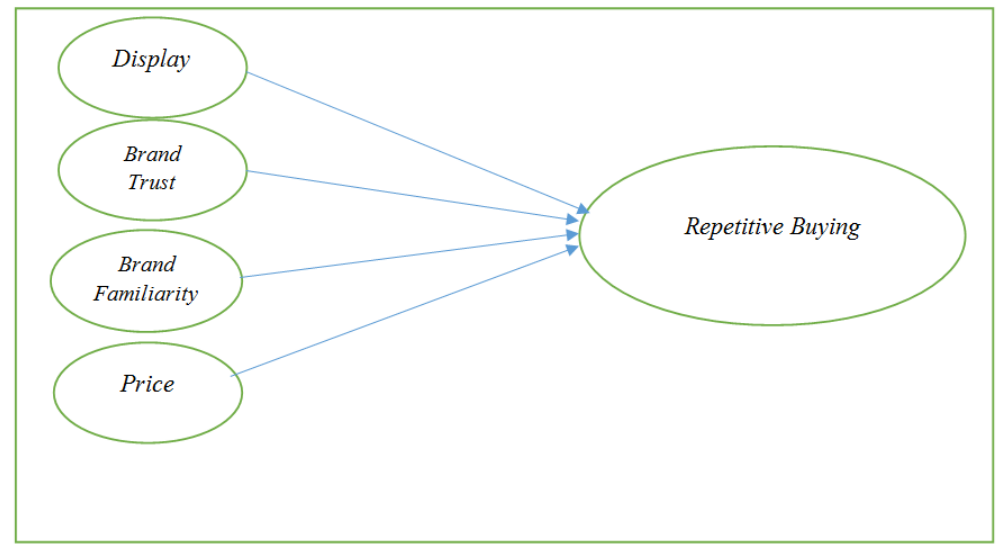

\section{RESEARCH METHODS}

\subsection{RESEARCH SAMPLES}

The sampling technique used in this study is non-probability sampling where the questionnaire is the main means of collecting data. Non-probability sampling is used because the actual number of population is unknown and known, in other words, individuals do not get the same probability or possibility to be selected as a sample. For this study, 200 samples were taken. Data was collected using a questionnaire distributed to respondents in accordance with the characteristics of the sample previously described. After filling out the questionnaire, the respondent returns the questionnaire that has been filled in and will then be selected.

\subsection{ANALYSIS METHOD}

To analyze the data used multiple linear regression of the SPSS statistical software package in modeling and hypothesis testing. Multiple linear regression is a set of statistical techniques that allows testing a series of relatively "complex" relationships simultaneously. The complex relationship can be built between one or more dependent variables with one or more independent variables. Each of the dependent and independent variables can be in the form of factors (or constructs, which are built from several indicator variables).

\section{RESULTS}

\subsection{Findings}

This study used Multiple Regression in testing between the variables. Statistical analysis tool used to answer the problem formulation of this research is SPSS 22.0. Once the questionnaires were 
returned, the next step that must be conducted is descriptive statistic-analysis. In Table 1, it shows that respondents who fill out questionnaires are mostly done by men, this can be seen from 104 respondents (52\%) of respondents who purchase on Holland Bakery while 96 respondents (48\%) are men. This indicates that customer of Holland bakery mostly is men.

\begin{tabular}{|l|l|r|r|r|r|}
\hline \multicolumn{2}{|l|}{ Table 1.Respondents Characteristic by Gender } \\
\hline \multicolumn{2}{|l|}{} & Frequency & Percent & Valid Percent & $\begin{array}{l}\text { Cumulative } \\
\text { Percent }\end{array}$ \\
\hline \multirow{3}{*}{ Valid } & Female & 104 & 52.0 & 52.0 & 52.0 \\
\cline { 2 - 6 } & Male & 96 & 48.0 & 48.0 & 100.0 \\
\cline { 2 - 6 } & Total & 200 & 100.0 & 100.0 & \\
\hline \multicolumn{6}{|l}{ Source: own calculation } \\
\hline
\end{tabular}

From the results in Table 2, it can be seen that the characteristics of respondents based on age are dominated by age group 18-35 which is 149 respondents $(74,5 \%)$, followed by $36-50$ age group which is 43 respondents $(21,5 \%)$, and last age group which is become respondents is age group 51-60 which is 8 respondents (4\%). This shows that the majority of respondents are in the age of $18-35$ or millenials.

\begin{tabular}{|c|c|c|c|c|c|}
\hline & & Frequency & Percent & Valid Percent & $\begin{array}{l}\text { Cumulative } \\
\text { Percent }\end{array}$ \\
\hline \multirow[t]{4}{*}{ Valid } & $18-35$ & 149 & 74.5 & 74.5 & 74.5 \\
\hline & $36-50$ & 43 & 21.5 & 21.5 & 96.0 \\
\hline & $51-60$ & 8 & 4.0 & 4.0 & 100.0 \\
\hline & Total & 200 & 100.0 & 100.0 & \\
\hline
\end{tabular}

\begin{tabular}{|l|r|r|r|}
\hline \multicolumn{4}{|l|}{ Table 3. Descriptive Statistics } \\
\hline & $\mathrm{N}$ & Mean & \multicolumn{1}{l|}{ Std. Deviation } \\
\hline DI1 & 200 & 3.940 & .7274 \\
\hline DI2 & 200 & 3.780 & .5596 \\
\hline DI3 & 200 & 3.765 & .6417 \\
\hline DI & 200 & 3.8283 & .5111 \\
\hline BT1 & 200 & 3.780 & .7840 \\
\hline BT2 & 200 & 3.790 & .6228 \\
\hline
\end{tabular}




\begin{tabular}{|l|r|r|r|}
\hline BT3 & 200 & 3.775 & .5968 \\
\hline BT & 200 & 3.781 & .5107 \\
\hline BF1 & 200 & 4.085 & .8314 \\
\hline BF2 & 200 & 4.080 & .7459 \\
\hline BF3 & 200 & 3.925 & .7631 \\
\hline BF & 200 & 4.0299 & .6659 \\
\hline PR1 & 200 & 4.010 & .5758 \\
\hline PR2 & 200 & 3.860 & .4258 \\
\hline PR3 & 200 & 3.835 & .4570 \\
\hline PR4 & 200 & 3.815 & .4919 \\
\hline PR & 200 & 3.8800 & .35529 \\
\hline RB1 & 200 & 3.890 & .5091 \\
\hline RB2 & 200 & 3.860 & .5017 \\
\hline RB3 & 200 & 3.725 & .5576 \\
\hline RB4 & 200 & 3.870 & .5142 \\
\hline RB & 200 & 3.8363 & .39833 \\
\hline Valid N (listwise) & 200 & & \\
\hline Source: own calculation & & & \\
\hline
\end{tabular}

Based on the results from data processing in table 3, it shows that all average score of the mean for overall indicator is above 3.61. This shows that all indicators of variables that tested can be perceived positive by all respondents. In addition, the standard deviation is under 2.0. This shows that the answers given by respondents are homogeneous or relatively the same. It is known that the highest mean average is brand familiarity is 4,0299 This may indicate that the indicators of brand familiarity are best perceived by the respondents than other variables. brand familiarity has the highest score for standard deviation, that is 0,6659 . This may indicate that the respondents give answers for brand familiarity least homogeneous compared with other variables.

Before going for Single Regression and Multiple Regression testing, first steps that must be conducted is the testing of the validity and reliability to prove that the data from the questionnaire is valid, reliable and able to be used for the next analysis.

\subsubsection{Validity Test}

The criteria is if the value of the factor loading is higher than 0.50 , then the statement is considered valid, however, if the value of the factor loading is less than the 0.50 , then the statement is considered invalid or failed. Based on the test of the data validity, it is prove that all indicators used to estimate each variable are valid, since the value of the factor loading for every questions are more than 0.50 . 


\begin{tabular}{|c|c|c|c|c|c|c|c|c|c|}
\hline Indicator & FL & Indicator & FL & Indicator & FL & Indicator & FL & Indicator & FL \\
\hline \multicolumn{2}{|l|}{ Display } & \multicolumn{2}{|c|}{ Brand trust } & \multicolumn{2}{|c|}{ Brand familiarity } & \multicolumn{2}{|l|}{ Price } & \multicolumn{2}{|c|}{ Repetitive buying } \\
\hline DI1 & .445 & BT1 & .450 & $\mathrm{BF} 1$ & .639 & PR1 & .460 & RB1 & .440 \\
\hline DI2 & .564 & $\mathrm{BT} 2$ & .427 & $\mathrm{BF} 2$ & .740 & PR2 & .468 & RB2 & .654 \\
\hline DI3 & .567 & BT3 & .470 & $\mathrm{BF} 3$ & .617 & PR3 & .523 & RB3 & .576 \\
\hline & & & & & & PR4 & .497 & RB4 & .588 \\
\hline
\end{tabular}

\subsubsection{Reliability Test}

Reliability test is do by comparing cronbach's alpha value, if the value is higher than 0.6 , then the statement is considered reliable.

\begin{tabular}{|c|c|}
\hline Variable & $\begin{array}{l}\text { Cronbach's Alpha Based on } \\
\text { Standardized Items }\end{array}$ \\
\hline Display & .712 \\
\hline Brand Trust & .641 \\
\hline Brand Familiarity & .815 \\
\hline Price & .704 \\
\hline Repetitive buying & .764 \\
\hline
\end{tabular}

From the table 5, it is proven that the variable of display, brand trust, brand familiarity, price, repetitive buying having the Cronbach alpha value higher than 0.60 . So, it can be concluded that the statements develop the variables can be said to be consistent/reliable and can be used for further analysis.

\subsubsection{Results of Multiple Regression Display, brand trust, brand familiarity, and price to repetitive} buying

The results of multiple regression are as follows:

\begin{tabular}{|c|c|c|c|c|c|c|}
\hline \multicolumn{7}{|c|}{ Table 8. Coefisien Regression Model 1} \\
\hline \multirow{2}{*}{\multicolumn{2}{|c|}{ Model }} & \multicolumn{2}{|c|}{ Unstandardized Coefficients } & \multirow{2}{*}{\begin{tabular}{|l|} 
Standardized \\
Coefficients \\
Beta \\
\end{tabular}} & \multirow[b]{2}{*}{$\mathrm{T}$} & \multirow[b]{2}{*}{ Sig. } \\
\hline & & $\mathrm{B}$ & Std. Error & & & \\
\hline \multirow[t]{4}{*}{1} & (Constant) & .991 & 346 & & 2.861 & .005 \\
\hline & DI & .230 & .048 & .295 & 4.804 & .000 \\
\hline & BT & .203 & .048 & .260 & 4.270 & .000 \\
\hline & $\mathrm{BF}$ & .132 & .038 & .220 & 3.508 & .001 \\
\hline
\end{tabular}




\begin{tabular}{|l|l|r|r|r|r|}
\hline \multicolumn{1}{|l|}{ PR } & .172 & .071 & .153 & 2.430 & .016 \\
\hline a. Dependent Variable: RB \\
Source: own calculation
\end{tabular}

From table 8, the regression equation can be written as follows:

$$
\begin{aligned}
& \mathrm{RB}=\mathrm{b} 1 \mathrm{DI}+\mathrm{b}_{2} \mathrm{LBT}+\mathrm{b}_{3} \mathrm{BF}+\mathrm{b}_{4} \mathrm{PR} \\
& \mathrm{RB}=0.295 \mathrm{DI}+0,260 \mathrm{BT}+0.220 \mathrm{BF}+0.153 \mathrm{PR}
\end{aligned}
$$

Based on table 8 , all the independent variables have positively influence towards repetitive buying. Display has the greatest regression coefficient compare to other variables, that is 0,295 . Therefore, Display is the most influence to repetitive buying. In the other side, brand familiarity has the smallest effect on repetitive buying, that is 0,153 .

\subsubsection{Regression t-test Display, brand trust, brand familiarity, and price to repetitive buying}

The $t$ test used to determine whether the independent variables of in display, brand trust, brand familiarity and price partially (independently) have significant influence on repetitive buying. If the value of $t$ test is below 0.05 , then it can be stated that the variable is significantly influenced by partially. From table 14 , it can be seen that display, brand trust, brand familiarity and price partially (independently) have significant

\begin{tabular}{|c|c|c|c|c|c|c|}
\hline \multicolumn{7}{|c|}{ Table 14. Result of t-test } \\
\hline \multirow{2}{*}{\multicolumn{2}{|c|}{ Model }} & \multicolumn{2}{|c|}{ Unstandardized Coefficients } & \multirow{2}{*}{$\begin{array}{l}\text { Standardized } \\
\text { Coefficients } \\
\text { Beta }\end{array}$} & \multirow[b]{2}{*}{$\mathrm{T}$} & \multirow[b]{2}{*}{ Sig. } \\
\hline & & $\mathrm{B}$ & Std. Error & & & \\
\hline \multirow[t]{5}{*}{1} & (Constant) & .991 & .346 & & 2.861 & .005 \\
\hline & DI & .230 & .048 & .295 & 4.804 & .000 \\
\hline & BT & .203 & .048 & .260 & 4.270 & .000 \\
\hline & $\mathrm{BF}$ & .132 & .038 & .220 & 3.508 & .001 \\
\hline & PR & .172 & .071 & .153 & 2.430 & .016 \\
\hline \multicolumn{7}{|c|}{ a. Dependent Variable: RB } \\
\hline \multicolumn{7}{|c|}{ Source: own calculation } \\
\hline
\end{tabular}
influence on repetitive buying.

\section{ANALYSIS AND DISCUSSION}


The results of this study shows that the variables display, brand trust, brand familiarity, and price have positive and significant effects on repetitive buying. So, the conclusion is that from four proposed hypotheses, all hypotheses are supported.

The first hypothesis stating that display has a positive significant effect on repetitive buying is supported. The first hypothesis stating that display has a positive effect on repetitive buying is supported because the $t$ test value is 0.000 , below 0.05 . This shows the consistency results of this study with Foster (2008) that states that service quality have a significant positive effect on repetitive buying.

The second hypothesis stating that brand trust has a positive significant effect on repetitive buying is accepted. The second hypothesis stating that brand trust has a positive effect on repetitive buying is supported because the t test value is 0.000 below than 0.05 . This shows the consistency results of this study with Lianda (2009)

The third hypothesis stating that brand familiarity has a positive significant effect on repetitive buying is supported. The third hypothesis stating that brand familiarity has a positive effect on repetitive buying is supported because the t test value is 0.001 , below 0.05 . This shows the consistency results of this study with Khasawneh (2010) that states that brand familiarity have a significant positive effect on repetitive buying.

The fourth hypothesis stating that price has a positive significant effect on repetitive buying is supported. The fourth hypothesis stating that price has a positive effect on repetitive buying is supported because the $t$ test value is 0.016 below 0.05 . This shows the consistency results of this study with Dodds (1991) that states that price have a significant positive effect on repetitive buying.

\section{CONCLUSION AND RECOMMENDATION}

This model was developed in order to research repetitive buying for Holland Bakery in Surabaya. This research model formed an influence relationship between display, brand trust, brand familiarity, and price to repetitive buying. So, the conclusion is that from four proposed hypotheses, all hypotheses are supported.

Display significantly influences customer satisfaction, which means that the first hypothesis is accepted. This statement is in line with the study conducted by Foster (2008). If customer see beautiful display from the Holland Bakery store, the customer is likely to be interesting and easily engage to the store. Therefore, it will the customer to have repetitive buying. So, Holland bakery should pay attention especially on store and product display.

The analysis result of the research model reveals that brand trust significantly influences repetitive buying, which means that the second hypothesis is accepted. This statement is in line with the study conducted by Lianda (2009). If the customer feels that the brand trust of Holland is good, then the customer will trust to Holland bakery product and this can lead the customer to have repetitive buying. So, Holland bakery have to gain brand trust from customer, especially because Holland bakery sell consumer product and consumer should trust first to have repetitive buying.

The analysis result of the research model reveals that brand familiarity significantly influences repetitive buying. This means that the fourth hypothesis is accepted. This statement is in line with the statement proposed by Dodds (1991) who said to have repetitive buying, company first 
should have brand familiairity. So, Holland bakery should focus to increase brand familiarity by setting proper advertising to make customer more familiar with brand of Holland bakery.

The analysis result of the research model reveals that price significantly influences repetitive buying. From the model analysis outcome shows that price has a sigificant influence on customer satisfaction, which means that the third hypothesis is accepted. This statement is in line with the statement stated by Khasawneh (2010). It shows that the customer of Holland bakery is very sensitive on the price, despite of tight competition with other bread producers. Therefore, Holland bakery should pay attention on their pricing strategy to make it affordable for customer.

\section{References}

Aaker, David A. 2008.ManajemenEkuitas Merek: Memanfaatkan Nilai dari suatu Merek.Terjemahan oleh Aris Ananda. Cetakan Ketiga. Jakarta: Mitra Utama

Adrian Hartono (2012). Pengaruh Display, Kepercayaan Merek, Keakraban Merek, Persepsi, Harga Terhadap Intensi Pembelian dan Pembelian Tak Terencana. Jurnal Ekonomika Bisnis Universitas Kristen Satya Wacana, dan 1 (1), 1 - 22

Basu Swastha, 2008, Manajemen Pemasaran Analisis Perilaku Konsumen, Liberty, Yogyakarta.

Delgado-Ballester, E., Munuera-Alemán, J.L., (2005). Does brand trust matter to brand equity?. Journal of Product and Brand Management, 14 (3), 187-196.

Ferdinand, A. (2002). Structural equation modelling dalam penelitian manajemen. Semarang: Universitas Diponegoro.

Fogarty, G., Catts, R., \& Forlin, C. (2000). Identifying shortcomings in the measurement of service quality. Journal of Outcome Measurement, 4(1), 425-447.

Kotler, Philip. (2000). Marketing Management, The Millenium Edition, New Jersey: Prentice Hall International, Inc.

Kotler, Philip. 2007. Manajemen Pemasaran, Analisis Perencanaan, Pengendalian, Prentice Hall, Edisi Bahasa Indonesia, Jakarta: Salemba Empat

Lane, V. and Jacobson, R. (1995) "Stock Market reactions to brand extention announcements: The effects of brand attitude and familiarity," Journal of Marketing, Vol. 59 No.1, pp. 63-77

Sahin, A., Zehir C.,\& Kitapci H. (2011) The Effects of Brand Experiences, Trust and Satisfaction on Building Brand Loyalty; An Empirical Research On Global Brands. Journal of International Strategic Management Conference Vol : 7, 1288-1301.

Schiffman \& Kanuk. (2007), Perilaku Konsumen, dialihbahasakan oleh Zulkifli Kasip, Edisi Ketujuh, Penerbit PT. Indexs 
Shultz, Willian J. (2004). Outline of Marketing, Littlefield, Adam \& Co

Tjiptono, F., 2002. Manajemen Jasa, Edisi II. Cetakan ketiga. Yogyakarta : Andi Offset

Zeithaml, Parasuraman, Berry .1990. "Delivering Quality Service”, New York : The Free Press 